\title{
Investigation of Different Materials as Buffer Layer in CZTS Solar Cells Using SCAPS
}

\author{
Md. Noumil Tousif, Sakib Mohammad, A. A. Ferdous, and Md. Ashraful Hoque
}

\begin{abstract}
Cadmium sulfide (CdS) is widely used as buffer layer of $\mathrm{Cu}_{2} \mathrm{ZnSnS}_{4}$ (CZTS)-based thin film solar cell. Due to its toxicity, its alternatives are being explored. In this work, with an attempt to find an alternative to Cadmium sulfide, electrical performances of solar cell with different buffer layers were simulated and recorded. Simulation was carried out with Solar Cell Capacitance Simulator (SCAPS). As buffer layer, other than Cds; $\mathrm{Zn}(\mathrm{O}, \mathrm{S}), \mathrm{ZnS}, \mathrm{ZnSe}, \mathrm{InS}$ and $\mathrm{MoS}_{2}$ were separately used. Zinc compounds are cheap, eco-friendly and they have relatively higher band gap, making them suitable candidate for replacing CdS. $\mathrm{Zn}(\mathrm{O}, \mathrm{S})$ and $\mathrm{ZnS}$ yielded good results with conversion efficiency of $10.28 \%$ and $9.82 \%$ respectively. This result is favorable for cost-effective fabrication of highly efficient thin film solar cell.
\end{abstract}

Index Terms-Buffer layer, CdS, CZTS, InS, $\mathrm{MoS}_{2}$, SCAPS, Zn(O,S), ZnSe, ZnS.

\section{INTRODUCTION}

In the present state of Solar cells, it is highly recommended to fabricate low cost, high energy conversion efficiency solar cells [1] We have used most of our fossil fuels and by the end of this century, all of it will be depleted [2]-[4] Hence we have to find an alternative source of energy and renewable energy i.e Solar energy is the best option amongst the rest.

Primarily, there are two types of solar cells; thin type \& bulk type. Being cheaper in price, thin type solar cell became much popular than the other type. Among them CdTe (Cadmium Telluride) and CIGS (CuInGa(S,Se2)) solar cells have the highest uses \& the efficiency. [5], [6]. Although in the last decade, CdTe has gained much interest as an absorber layer for having the maximum energy conversion efficiency of $17.3 \%$ [7] and CIGS solar cells reached around $20 \%$ [8] of energy conversion efficiency, having been found the toxic materials in their constituents, these are not eco-friendly. And also these aren't earth abundant but costly on the other hand. By considering environment friendliness and abundancy in earth's crust and the cost effectivity, CZTS is the best possible option for using it as an absorber layer in Solar Cells Thin film Cu2ZnSnS4 (CZTS) solar cell is a potential source of low-cost, high efficiency solar electricity [9]. Its constituents are eco-friendly and these have been found much abundant in earth's crust. [10]-[13]. Indeed, CZTS is one of the most prospective materials to be used as solar cell absorber layer, due to its excellent optical properties (the

Manuscript received February 1, 2018; revised July 5, 2018.

The authors were with the Department of Electrical and Electronic Engineering, Islamic University of Technology, Gazipur, Bangladesh (e-mail: noumiltousif@gmail.com, sakibmohammad1994@gmail.com, aferdous@iut-dhaka.edu and mahoque@iut-dhaka.edu). band gap varies from 1.4 to $1.5 \mathrm{eV}$ and the absorption coefficient is higher than $104 \mathrm{~cm}-1$ [14]-[17]

Now in our case, we will use CZTS as absorber layer and different materials such as cadmium sulfide $(\mathrm{CdS}), \mathrm{Zn}(\mathrm{O}, \mathrm{S})$, zinc sulfide $(\mathrm{ZnS})$, zinc selenide ( $\mathrm{ZnSe})$, indium sulfide $(\mathrm{InS})$, molybdenum sulfide (MoS2) as buffer layer. The main theme of this simulation is to see the viability of the materials for buffer layers. CZTS thin-film solar cell with the structure of SLG/Mo/CZTS/buffer layer/Al:ZnO was implemented in the SCAPS 3302 environment. The default illumination spectrum and operation temperature were set to the global AM1.5 standard and $300 \mathrm{~K}$, respectively.

\section{Device Modeling}

The modeling calculations discussed in the following section is done by the software named Solar Cells Capacitance Simulator (SCAPS). SCAPS is a Solar Cell simulation software which was developed under Professor Marc Burgelman in the Department of electronics and information system at University of Ghent, Belgium [18][20].

The CZTS structure was made up of a p-type CZTS absorber layer, the buffer layer and n-type $\mathrm{Al}: \mathrm{ZnO}$. Molybdenum was used as a back contact and the entire structure was placed on a substrate of Soda Lime Glass. For buffer layer, $\mathrm{ZnS}$ is used, but the other materials- $\mathrm{CdS}, \mathrm{Zn}(\mathrm{O}$, $\mathrm{S}), \mathrm{ZnSe}, \mathrm{InS} \& \mathrm{MoS} 2$ was used for simulation.

Here CZTS solar cell with the structure of CZTS/buffer layer/Al: $\mathrm{ZnO}$ was implemented in the SCAPS 3302. The basic input parameters used in the simulation were adopted from different literatures, theories and some of them were from reasonable estimates in Table I and Table II. The default illumination spectrum and operation temperature were set to the global AM1.5 standard and $300 \mathrm{~K}$, respectively.

\section{RESULTS}

The performance characteristics of our solar cell models are summarized in Table II. The corresponding J-V curves are shown in Fig. 2-5 respectively. In our simulation $\mathrm{Zn}(\mathrm{O}, \mathrm{S})$ buffer layer produced the highest efficiency which is $10.28 \%$. It is to be noted that the performances of $\mathrm{CdS}$ and $\mathrm{Zn}(\mathrm{O}, \mathrm{S})$ buffer layers were almost identical $\mathrm{CdS}$ fell behind $\mathrm{Zn}(\mathrm{O}, \mathrm{S})$ only by $0.02 \%$ (actual efficiency is $10.26 \%$ ). Also $\mathrm{ZnS}$ showed promising results with good electrical parameters and an efficiency of $9.82 \%$. However the other three materials ( $\mathrm{ZnSe}, \mathrm{InS}, \mathrm{MoSe} 2)$ showed poor results. ZnSe had a poor energy conversion efficiency of only $1.58 \%$, while the 
Mo|CZTS|InS|Al:ZnO structures failed to converge, that means these buffer layers ( $\mathrm{InS}, \mathrm{MoSe} 2)$ are not viable for our model and they will not produce any energy when put under sunlight.

TABLE I: PARAMETERS USED IN THE SimULATION (1)

\begin{tabular}{|c|c|c|c|c|}
\hline $\begin{array}{l}\text { Parameter } \\
\mathrm{s}\end{array}$ & $\begin{array}{l}\text { CZTS [21] } \\
{[22][23]}\end{array}$ & CdS & $\begin{array}{l}\mathbf{Z n}(\mathbf{O}, \mathbf{S}) \\
{[24][25]} \\
{[23]} \\
\end{array}$ & $\overline{Z z n S ~[9] ~}$ \\
\hline $\begin{array}{l}\text { Thickness } \\
(\mathrm{nm})\end{array}$ & 2000 & 50 & 50 & 60 \\
\hline $\begin{array}{l}\text { Bandgap } \\
(\mathrm{eV})\end{array}$ & 1.5 & 2.4 & 2.7 & 3.5 \\
\hline $\begin{array}{l}\text { Electron } \\
\text { affinity } \\
\text { (eV) }\end{array}$ & 4.5 & 4.5 & 4.3 & 4.5 \\
\hline $\begin{array}{l}\text { Dielectric } \\
\text { permittivity } \\
\text { (relative) }\end{array}$ & 6.5 & 10 & 10 & 10 \\
\hline $\begin{array}{l}\text { CB } \\
\text { effective } \\
\text { density of } \\
\text { states } \\
\left(1 / \mathrm{cm}^{3}\right) \\
\end{array}$ & $2.07 * 10^{18}$ & $2.0^{2 * 10^{18}}$ & $2.2^{2} * 10^{18}$ & $1.5^{2} * 10^{18}$ \\
\hline $\begin{array}{l}\text { VB } \\
\text { effective } \\
\text { density of } \\
\text { states } \\
\left(1 / \mathrm{cm}^{3}\right)\end{array}$ & $8.85 * 10^{18}$ & $1.5^{*} 10^{19}$ & $1.8 * 10^{19}$ & $1.8^{*} * 10^{18}$ \\
\hline $\begin{array}{l}\text { Electron } \\
\text { mobility } \\
\left(\mathrm{cm}^{2} / \mathrm{Vs}\right)\end{array}$ & 26 & $\overline{250}$ & 100 & 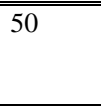 \\
\hline $\begin{array}{l}\text { Hole } \\
\text { Mobility } \\
\left(\mathrm{cm}^{2} / \mathrm{Vs}\right)\end{array}$ & 10 & 20 & 25 & 20 \\
\hline $\begin{array}{l}\text { Shallow } \\
\text { uniform } \\
\text { donor } \\
\text { density, } \mathrm{N}_{\mathrm{D}} \\
\left(1 / \mathrm{cm}^{3}\right)\end{array}$ & 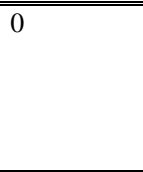 & $1^{\prime * 10^{17}}$ & $1 * 11^{17}$ & 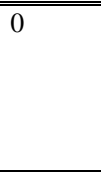 \\
\hline $\begin{array}{l}\text { Shallow } \\
\text { uniform } \\
\text { acceptor } \\
\text { density, } \mathrm{N}_{\mathrm{A}} \\
\left(1 / \mathrm{cm}^{3}\right)\end{array}$ & $1 * 10^{16}$ & 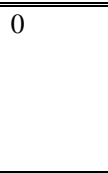 & 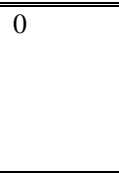 & $1 * 10^{17}$ \\
\hline
\end{tabular}

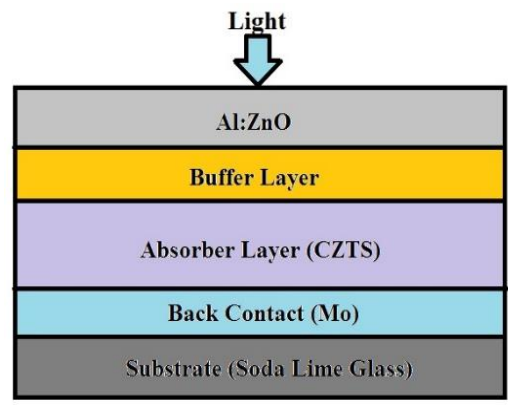

Fig. 1. Structure of a CZTS solar cell.

Current Density

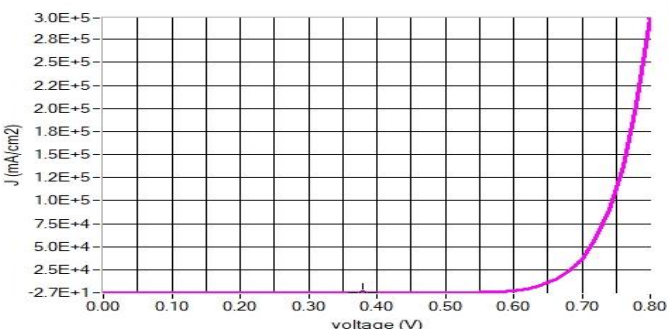

Fig. 2. Light characteristic curve ( $\mathrm{J}$ vs $\mathrm{V}$ ) of simulation with $\mathrm{CdS}$ buffer layer.
TABLE II: PARAMETERS USED IN THE SIMULATION (2)

\begin{tabular}{|c|c|c|c|c|}
\hline $\begin{array}{l}\text { Parameter } \\
\text { S }\end{array}$ & ZnSe [9] & InS [9] & $\mathbf{M o S}_{2}[26]$ & $\begin{array}{l}\mathbf{A l : Z n O} \\
{[27][28]}\end{array}$ \\
\hline $\begin{array}{l}\text { Thickness } \\
(\mathrm{nm})\end{array}$ & 80 & 50 & 40 & 200 \\
\hline $\begin{array}{l}\text { Bandgap } \\
(\mathrm{eV})\end{array}$ & 2.9 & 2.8 & 1.29 & 3.4 \\
\hline $\begin{array}{l}\text { Electron } \\
\text { affinity } \\
(\mathrm{eV})\end{array}$ & 4.09 & 4 & 4.2 & 4.6 \\
\hline $\begin{array}{l}\text { Dielectric } \\
\text { permittivity } \\
\text { (relative) }\end{array}$ & 10 & 13.5 & 4 & 9 \\
\hline $\begin{array}{l}\text { CB } \\
\text { effective } \\
\text { density of } \\
\text { states } \\
\left(1 / \mathrm{cm}^{3}\right) \\
\end{array}$ & $1.5^{*} * 10^{18}$ & $1.8 * 10^{19}$ & $7.5^{*} 10^{17}$ & $4 * 10^{18}$ \\
\hline $\begin{array}{l}\text { VB } \\
\text { effective } \\
\text { density of } \\
\text { states } \\
\left(1 / \mathrm{cm}^{3}\right)\end{array}$ & $1.8 * 10^{18}$ & $4^{*} 10^{13}$ & $1.8 * 10^{18}$ & $9 * 10^{18}$ \\
\hline $\begin{array}{l}\text { Electron } \\
\text { mobility } \\
\left(\mathrm{cm}^{2} / \mathrm{Vs}\right)\end{array}$ & 50 & 400 & 100 & 100 \\
\hline $\begin{array}{l}\text { Hole } \\
\text { Mobility } \\
\left(\mathrm{cm}^{2} / \mathrm{Vs}\right) \\
\end{array}$ & 20 & 210 & 150 & 31 \\
\hline $\begin{array}{l}\text { Shallow } \\
\text { uniform } \\
\text { donor } \\
\text { density, } \mathrm{N}_{\mathrm{D}} \\
\left(1 / \mathrm{cm}^{3}\right) \\
\end{array}$ & 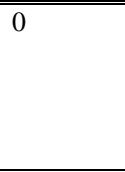 & 10 & 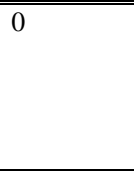 & $1 * 10^{20}$ \\
\hline $\begin{array}{l}\text { Shallow } \\
\text { uniform } \\
\text { acceptor } \\
\text { density, } \mathrm{N}_{\mathrm{A}} \\
\left(1 / \mathrm{cm}^{3}\right)\end{array}$ & $5.5 * 10^{7}$ & $1^{*} 10^{18}$ & $1 * 10^{21}$ & $\overline{0}$ \\
\hline
\end{tabular}

TABLE III: SUMMARY OF PERFORMANCE CHARACTERISTICS OF THE SOLAR

\begin{tabular}{|l|l|l|l|l|}
\hline $\begin{array}{l}\text { Buffer } \\
\text { Layer }\end{array}$ & $\mathbf{V}_{\text {oc }}$ (volt) & $\mathbf{J}_{\text {sc }}\left(\mathrm{mA} / \mathrm{cm}^{2}\right)$ & FF (\%) & $\begin{array}{l}\text { Efficiency } \\
(\%)\end{array}$ \\
\hline $\mathrm{CdS}$ & 0.4804 & 27.1972 & 78.53 & 10.26 \\
\hline $\mathrm{Zn}(\mathrm{O}, \mathrm{S})$ & 0.4803 & 27.2320 & 78.57 & 10.28 \\
\hline $\mathrm{ZnS}$ & 0.4808 & 26.8472 & 76.22 & 9.82 \\
\hline $\mathrm{ZnSe}$ & 0.6220 & 22.1889 & 11.41 & 1.58 \\
\hline $\mathrm{InS}$ & - & - & - & - \\
\hline $\mathrm{MoS}_{2}$ & - & - & - & - \\
\hline
\end{tabular}

Current Density

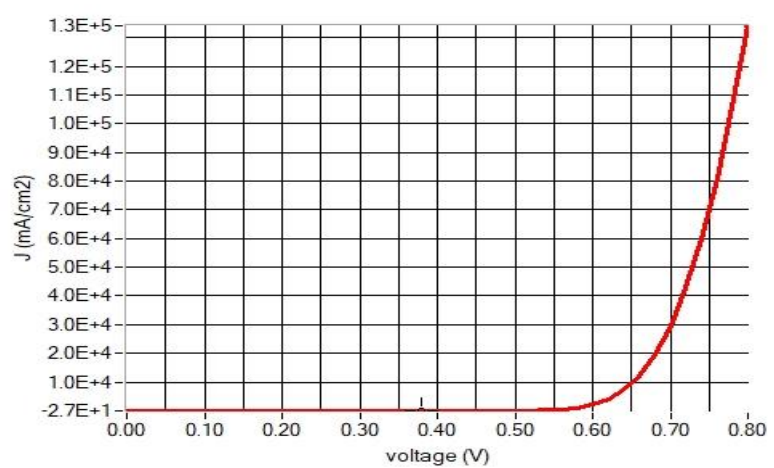

Fig. 3. Light characteristic curve (J vs V) of simulation with $\mathrm{Zn}(\mathrm{O}, \mathrm{S})$ buffer layer. 


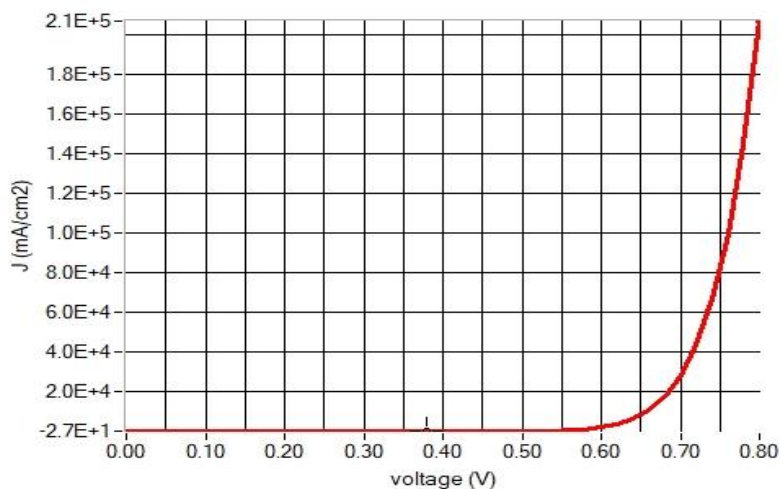

Fig. 4. Light characteristic curve (J vs V) of simulation with $\mathrm{ZnS}$ buffer layer.

Current Density

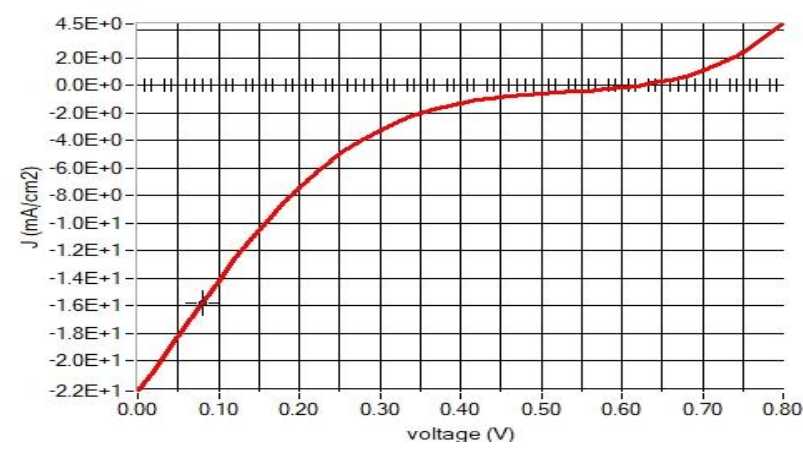

Fig. 5. Light characteristic curve (J vs V) of simulation with ZnSe buffer layer.

\section{CONCLUSION}

From the simulation it can be concluded that different materials can be successfully used with CZTS as buffer layer to implement a solar cell. Especially $\mathrm{Zn}(\mathrm{O}, \mathrm{S})$ and $\mathrm{ZnS}$ showed promising results and hence can be used as an alternative to $\mathrm{CdS}$, which causes serious environmental problem. The Zinc based compounds are abundant, cheap and environment friendly so they are perfect for mass production. One of the major challenges that remain is the comparatively low efficiency of CZTS based solar cells. There is much room for development. Cell models can be further optimized, different materials can be used. Much more improvement in efficiency can be expected from researches being conducted in this field.

\section{ACKNOWLEDGMENT}

We would like thank Islamic University of Technology and REASP for providing us full support we needed during this research.

\section{REFERENCES}

[1] N. Amin, M. I. Hossain, P. Chelvanathan, A. Mukter Uzzaman, and K. Sopian, "Prospects of $\mathrm{Cu}_{2} \mathrm{ZnSnS}_{4}$ (CZTS) Solar Cells from," in Proc. 6th International Conference on Electrical and Computer Engineering, Dhaka, 2010.

[2] S. Goldenburg. (8 June, 2015). The Guardian. [Online]. Available: http://www.theguardian.com/world/2015/jun/08/g7-

[3] M. McGrath, BBC news," 2 November 2014. [Online]. Available: http://ww2w.bbc.com/news/science-environment-29855884.

[4] C. Jamasmie. (8 June, 2015). Mining.com. [Online]. Available: http://www.mining.com/g7-agrees-to-phase-out-fossil-fuels-byend-
[5] K. Zweibel and R. Noufi, "High-efficiency CdTe and CIGS thin-film solar cells: Highlights and challenges," in IEEE, Hawaii, 2006.

[6] P. Grana. (November 10, 2010). Renewable Energy World. [Online]. Available:

http://www.renewableenergyworld.com/ugc/blogs/2010/11/the-efficie ncy-race-how-to-cdte-and-cigs-stack-up.html

[7] M. A. Green, K. Emery, Y. Hishikawa, W. Warta, and E. D. Dunlop, Solar Cell Efficiency Tables, Progress in Photovoltaics: Research \& Applications, 2012.

[8] R. Niderost. (18 January 2013). Empa materials science and technology. [Online]. Available: https://www.empa.ch/web/s604/weltrekord

[9] M. A. Olopade, O. O. Oyebola, and B. S. Adeleke, "Investigation of some materials as buffer layer in copper zinc tin sulphide $\left(\mathrm{Cu}_{2} \mathrm{ZnSnS}_{4}\right)$ solar cells by SCAPS-1D," Advances in Applied Science Research, pp 3396-3400, 2012.

[10] C. Zhang, J. Zhong, and Z. Tang, $\mathrm{Cu}_{2} \mathrm{ZnSn}(\mathrm{S}, \mathrm{Se})_{4}$ Thin Film Solar Cells Fabricated with Benign, in Higher Education Press and Springer-Verlag Berlin Heidelberg, Heidelberg, 2015.

[11] B. Mahalakshmi and M. R. Ananthan, "Review on CZTS based solar cells," Advances in Natural and Applied Sciences, 2014.

[12] T. P. Dhakal and P. S. Vasekar, Thin Film Solar Cells Using Earth Abundant Materials, Solar Cells-Research \& Application Perspectives.

[13] B. Shin, O. Gunawan, Y. Zhu, N. A. Bojarczuk, S. J. Chey, and S. Guha, "Thin film solar cell with $8.4 \%$ power conversion efficiency using an earth-abundant Cu2ZnSnS4 absorber," IBM T. J. Watson Research Center, Yorktown Heights, New York, 2013.

[14] A. Wangperawong, J. S. King, S. M. Herron, B. P. Tran, and K. Pangan-Okimoto, "Aqueous bath process for deposition of Cu2ZnSnS4 photovoltaic absorbers," Thin Solid Films, vol. 519, no. 8, pp. 2488-2492, 2011.

[15] H. Araki, Y. Kubo, and K. Jimbo, "Preparation of $\mathrm{Cu}_{2} \mathrm{ZnSnS}_{4}$ thin films by sulfurization of co-electroplated $\mathrm{Cu}-\mathrm{Zn}$-Sn pre-cursors," Physica Status Solidi, vol. 6, no. 5, pp. 1266-1268, 2009.

[16] H. Katagiri, K. Saitoh, T. Washio, H. Shinohara, T. Kurumadani, and S. Miyajima, "Development of thin film solar cell based on $\mathrm{Cu}_{2} \mathrm{ZnSnS}_{4}$ thin films," Solar Energy Materials and Solar Cells, vol. 65, no. 1-4, pp. 141-148, 2001

[17] W. Zhao, W. Zhou, and X. Miao, "Numerical Simulations of Thin Film Solar Cells," in Proc. the 7th IEEE International Conference on Nano/Micro Engineered and Molecular Systems (NEMS '12), Kyoto, 2012.

[18] K. Decock, S. Khelifi, and M. Brgelman, Modelling Multivalent Defects in Thin Film Solar Cells, in Thin Solid Films, 2011.

[19] M. Mostefaoui, H. Maari, S. Khelifi, A. Bouraiou, and R. Dabou, "Simulation of high efficiency CIGS solar cells with SCAPS-1D software," Energy Procedia, vol. 74, 2015.

[20] M. Burgelman, J. Verschraegen, S. Degrave, and P. Nollet, "Modelling Thin-Film PV devices," Progress in Photovoltaics: Research \& Applications, vol. 12, no. 2-3, 2004.

[21] C. Frisk, T. Ericson, and S. Y. Li, "Combining strong interface recombination with bandgap narrowing and short diffusion length in $\mathrm{Cu}_{2} \mathrm{ZnSnS}_{4}$ device modeling," Solar Energ Matter, Solar Cells, vol. 144, pp. 364-370, 2014.

[22] M. Patel and A. Ray, "Enhancement of output performance of Cu2ZnSnS4 thin film solar cells - A numerical simulation approach and comparison to experiments," Phys. B, Condens. Matter, vol. 21, no. 407, pp. 4391-4397, 2012.

[23] M. T. Hsieh, S. J. Lue, and J. Ao, "Characterizations of chemical bath-deposited zinc oxysulfide films and the effects of their annealing on copper-indium-gallium-selenide solar cell efficiency," J. Power Sources, pp. 443-446, 2014.

[24] M. Buffiere, S. Harel, and C. Guillot-Deudon, "Effect of the chemical composition of co-sputtered $\mathrm{Zn}(\mathrm{O}, \mathrm{S})$ buffer layers on $\mathrm{Cu}(\mathrm{In}, \mathrm{Ga}) \mathrm{Se} 2$ solar cell performance," Phys. Status Solidi, pp. 282-290, 2015.

[25] S. Sharbati, S. H. Kashmiri, and J. T. McGroffin, "Improvement of CIGS thin-film solar cell performance by optimization of $\mathrm{Zn}(\mathrm{O}, \mathrm{S})$ buffer layer parameters," Applied Physics Advancement, pp. 1259-1265, 2015.

[26] M. Dey, M. Dey, T. Biswas, S. Alam, N. Amin, and M. A. Matin, "Modeling of $\mathrm{Cu}_{2} \mathrm{ZnSnS}_{4}$ Solar Cellswith Bismuth Sulphide as a Potential Buffer Layer," in Proc. the 5th International Conference on Informatics, Electronics \& Vision, Dhaka, 2016.

[27] J. P. Lin, Y. L. Lin., and L. J. Yu, "Numerical simulation of $\mathrm{Cu}_{2} \mathrm{ZnSnS}_{4}$ based solar cells with In2S3 buffer layers by SCAPS-1D," Journal of Applied Sciences and Engineering, vol. 17, pp. 383-390, 2014.

[28] D. A. Pogrebnyak, Y. N. Jamil and M. A. K. Muhammed, "Simultaion study of n-ZnO/p-Si Heterojunction solar cell," in наноматеріали, нанотехнологї̈, 2011. 


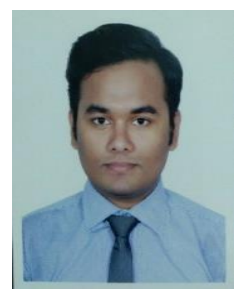

Md.Noumil Tousif received BSc in electrical and electronic engineering from Islamic University of Technology, Gazipur, Bangladesh in 2016.

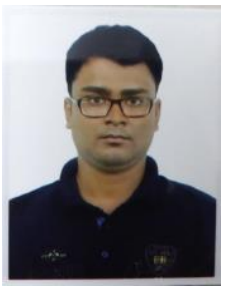

Sakib Mohammad received his B.Sc. in electrical and electronic engineering from the Islamic University of Technology (IUT), Gazipur, Dhaka, Bangladesh, in 2016.

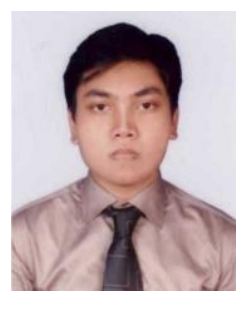

A. A. Ferdous obtained his bachelor's degree in 2016. He finished BSc in electrical and electronic Engineering from Islamic University of Technology, Gazipur, Bangladesh.

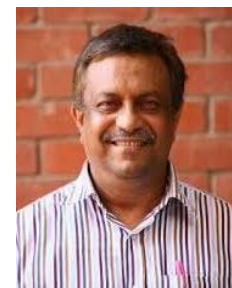

Md. Ashraful Hoque is the professor and head of the Department of the Department of Electrical and Electronic Engineering, Islamic University of Technology, Gazipur, Bangladesh. 